\title{
My mind is still mine: a self-portrait in a photography project for adolescents and young adults with cancer
}

\author{
Andrea Ferrari, Alice Patriccioli, Matteo Silva, Matteo Davide Bonvicini and Maura Massimino
}

\begin{abstract}
This commentary describes the unusual self-portrait contributed by a 26-year-old receiving treatment for relapsing medulloblastoma to a photography project undertaken by a group of patients as part of the Youth Project, a scheme dedicated to young cancer patients with the dual aim of optimizing medical aspects of their care and promoting a holistic approach to their needs. The article briefly describes how creative projects can play an important part in giving young people with cancer new ways to tell their stories and express their feelings. There is still a limited understanding of the specific needs of adolescents and young adults with cancer, and it is important to draw attention to them and to the need to devise a person-centered approach to cancer patients in this age group.
\end{abstract}

Keywords: Adolescents, Cancer, Youth Project, Photography, Art, Psychological support

\section{Background}

A cancer diagnosis is traumatic and difficult to face at any age, but may be particularly challenging when it happens to young people. It can disrupt several delicate developmental processes underway in adolescence - a time for establishing identities, developing social relationships, gaining independence, or experimenting sexually, just to give a few examples. The psychosocial sphere of adolescents and young adults with cancer may be particularly fragile, giving rise to emotional, psychological and social challenges that healthcare providers need to bear in mind $[1,2]$.

\section{Main text}

"This is my self-portrait for today,

It shows the very essence of me.

The title of my photo can be

'I will try to fix you',

like that song by Coldplay.

* Correspondence: andrea.ferrari@istitutotumori.mi.it

Pediatric Oncology Unit, Fondazione IRCCS Istituto Nazionale dei Tumori, Via G. Venezian, 1 -20133 Milan, Italy
People are defined by their thoughts,

by their minds.

Their body is just a shell.

For almost any part of your body, you can get a replacement,

be it organic or artificial,

a transfusion, a transplant, a prosthesis.

But you're still you,

just with something added - or taken away,

depending on how you look at it.

But you can't replace your brain.

In my mind, lots of people have come

to "try to fix me" in my time of need,

to help me feel better.

But my brain has stayed the same.

My mind is still mine."

These are the words B. used to accompany a photo an MRI (magnetic resonance imaging) scan of his brain - that he presented as a self-portrait for a photography project (Fig. 1).

B. is now 26 years old. He is currently receiving treatment at our institute's pediatric oncology unit for a third

C C The Author(s). 2021 Open Access This article is licensed under a Creative Commons Attribution 4.0 International License, which permits use, sharing, adaptation, distribution and reproduction in any medium or format, as long as you give appropriate credit to the original author(s) and the source, provide a link to the Creative Commons licence, and indicate if changes were made. The images or other third party material in this article are included in the article's Creative Commons licence, unless indicated otherwise in a credit line to the material. If material is not included in the article's Creative Commons licence and your intended use is not permitted by statutory regulation or exceeds the permitted use, you will need to obtain permission directly from the copyright holder. To view a copy of this licence, visit http://creativecommons.org/licenses/by/4.0/ The Creative Commons Public Domain Dedication waiver (http://creativecommons.org/publicdomain/zero/1.0/) applies to the data made available in this article, unless otherwise stated in a credit line to the data. 


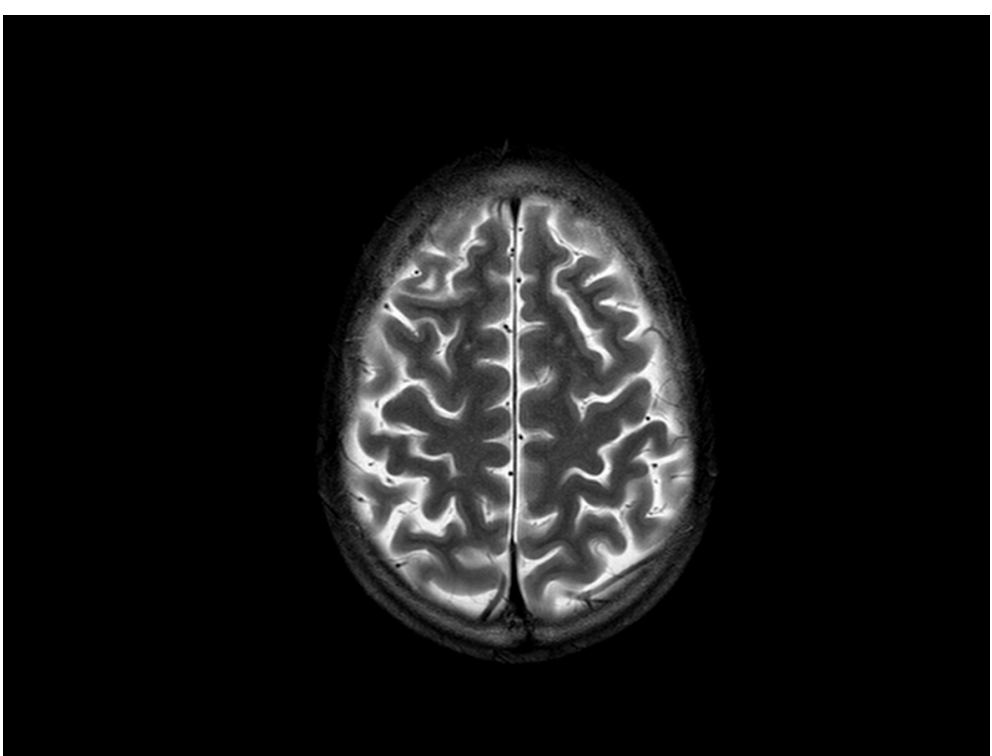

Fig. 1 The photo B. submitted of his brain MRI scan as a self-portrait for a photography project entitled "Looking out to see within"

relapse of his medulloblastoma, which was first diagnosed at 13 years of age. Over the years, he has been involved in many activities organized by the Youth Project, a scheme dedicated to young cancer patients with the dual purpose of optimizing medical aspects of their care while also paying attention to their quality of life (www. ilprogettogiovani.org) [3]. Launched in 2011, the Youth Project provides age-appropriate spaces in hospital and organizes creative activities that give patients special ways to express themselves more freely, to tell us about their fears and their hopes. Over the years, various projects involving photography, music, creative writing, and fashion design have been developed and reported [4-9]. The last creative laboratory organized as part of the Youth Project was a photography project entitled "Looking out to see within", run by a professional photographer from May to September 2020 [10]. B. took part in this project together with another 24 patients. As in previous projects, the patients who participated were adolescents and young adults (in principle aged 15-25 years, but the age limits were not strict) receiving treatment at the Pediatric Oncology Unit of the Istituto Nazionale dei Tumori in Milan, or those who had completed their treatments. No further specific inclusion/exclusion criteria were applied. Patients were invited to join this initiative by the Youth Project team (which includes dedicated doctors, psychologists and a youth worker) and were entirely free to do so or not. Patients (or their parents or legal guardians for those underage) gave their written informed consent to their involvement in the project. Participants met weekly on a digital platform to comply with social distancing rules due to the COVID-19 pandemic. The self-portrait was one of several themes covered by the photography project (the others were: the window through which we can look out on the world; and places and people we meet when we leave our room to go outside). As self-portraits, most participants submitted selfies, but B. sent a picture of his MRI. He said, "I can't imagine a better way to see inside myself'.

His words and his photograph exemplify many of the traits that we have seen in our adolescent and young adult patients working on these creative projects over the years. Our young participants in the Youth Project often reveal a sense of humor (a brain MRI as "my selfportrait for today"), a poetic spirit, an urge to speak freely about themselves, and a strong sense of selfdetermination ("my mind is still mine"). We believe that these characteristics, together with a self-deprecating attitude that we have often noted, may be fundamentally important to patients having to cope with the trauma of a diagnosis of cancer and its treatment at such a delicate developmental age.

\section{Conclusions}

We have learned from B. and other patients like him how important it is to organize projects and activities for our young patients to help them address the psychosocial challenges posed by their disease, and give them a chance to freely "voice" their fears and hopes. Far from being considered as "art therapy" (which relies on specific theoretical models), such creative projects should be seen as a form of psychological support, complementary to other more traditional approaches. They can open precious windows onto the inner worlds of our patients, enabling us to gain a better understanding of 
what they are really thinking and feeling, directly from their own words and artistic output. We have learned that creative projects have the potential to provide a much more genuine picture than we might obtain from structured specialist interviews. We believe that giving our patients the opportunity to freely "voice" their feelings is a fundamental part of helping them to process what is happening to them, to accept it and find the resources they need to cope with the whole period of their treatment in as positive a manner as possible. Using their creative spirit and art as a vehicle can make it easier for them to give vent to strong emotions, enabling them to express themselves in a more natural, less "controlled" way.

\section{Acknowledgements}

The authors thank the Associazione Bianca Garavaglia for supporting the Youth Project and the photographer Alice Patriccioli for the professional management of the photographic project. The photographs produced by the patients involved in the "Looking out to see within" project were used to make a calendar for 2021.

\section{Authors' contributions}

AF, MS and MM were mainly responsible for the study concept and design. AP and MDB were responsible for the acquisition of material. AF wrote the first draft of the manuscript. All authors edited the manuscript and then reviewed and approved the final version.

\section{Funding}

No financial support was received for this submission.

Availability of data and materials

Not applicable.

\section{Declarations}

\section{Ethics approval and consent to participate}

The Youth Project is approved by the Research Ethical Committee of the Fondazione IRCCS Istituto Nazionale dei Tumori, Milan, Italy (code 150053 of the Italian National Observatory on Clinical Trials).

All the patients (or parents/guardians in the case of minors) participating in the schemes organized by the Youth Project signed a written informed consent to their involvement in the project and to the use of their work.

\section{Consent for publication}

All the patients (or parents/guardians in case of minors) participating to the Youth Project signed a written informed consent for publication.

\section{Competing interests}

The authors declare that they have no competing interests.

Received: 10 February 2021 Accepted: 8 June 2021

Published online: 14 July 2021

\section{References}

1. Zebrack BJ. Psychological, social, and behavioral issues for young adults with cancer. Cancer 2011 May 15;117(10 Suppl):2289-94.

2. Morgan $S$, Davies $S$, Palmer $S$, Plaster M. Sex, drugs, and rock ' $n$ ' roll: caring for adolescents and young adults with cancer. J Clin Oncol. 2010;28(32): 4825-30.

3. Ferrari A, Clerici CA, Casanova M, Luksch R, Terenziani M, Spreafico F, et al. The Youth Project at the Istituto Nazionale Tumori in Milan. Tumori. 2012;98: 399-407.

4. Ferrari A, Veneroni L, Clerici CA, Casanova M, Chiaravalli S, Magni C, et al. Clouds of Oxygen: adolescents with cancer tell their story in music. J Clin Oncol. 2015;33(2):218-21.
5. Ferrari A, Gaggiotti P, Silva M, Veneroni L, Magni C, Signoroni S, et al. Searching for happiness. J Clin Oncol. 2017:35(19):2209-12

6. Ferrari A, Signoroni S, Silva M, Gaggiotti P, Veneroni L, Magni C, et al. "Christmas Balls": a Christmas carol by the adolescent cancer patients of the Milan Youth Project. Tumori. 2017;103(2):e9-14.

7. Signoroni S, Veneroni L, Pagani Bagliacca E, Gaggiotti P, Silva M, Casanova $M$, et al. "Summer is You": adolescents and young adults with cancer sing about their desire for summer. Pediatr Blood Cancer. 2019;66(5):e27630.

8. Ferrari A, Veneroni L, Signoroni S, Silva M, Gaggiotti P, Casanova M, et al. Loop: There's No Going Back: a graphic novel by adolescent cancer patients on the Youth Project in Milan. J Med Humanit. 2019;40(4):505-11.

9. Pagani Bagliacca E, Silva M, Veneroni L, Casanova M, Gasparini P, Signoroni $\mathrm{S}$, et al. YOU ${ }^{\text {TH: }}$ : the sweatshirt collection created by adolescent cancer patients on the Youth Project in Milan. Lancet Oncol. 2020 Mar;21(3):341-2.

10. Ferrari A, Patriccioli A, Silva M, Casanova M, Signoroni S, Massimino M. Looking out to see within: a photography project developed by adolescents with cancer during the COVID pandemic. Pediatr Blood Cancer. 2021 May;68(5):e28948.

\section{Publisher's Note}

Springer Nature remains neutral with regard to jurisdictional claims in published maps and institutional affiliations.

\section{Ready to submit your research? Choose BMC and benefit from:}

- fast, convenient online submission

- thorough peer review by experienced researchers in your field

- rapid publication on acceptance

- support for research data, including large and complex data types

- gold Open Access which fosters wider collaboration and increased citations

- maximum visibility for your research: over $100 \mathrm{M}$ website views per year

At $\mathrm{BMC}$, research is always in progress.

Learn more biomedcentral.com/submissions 